\title{
BANK MATURITY, INCOME DIVERSIFICATION, AND BANK STABILITY
}

\author{
Waqas TARIQ ${ }^{1}$, Muhammad USMAN ${ }^{*}$, Adeel TARIQ ${ }^{3}$, Robina RASHID $^{4}$, \\ Junming YIN ${ }^{5}$, Mumtaz Ali MEMON ${ }^{6}$, Muhammad ASHFAQ ${ }^{7}$ \\ ${ }^{1}$ Department of Commerce, University of Sialkot, Sialkot, Pakistan \\ ${ }^{2}$ School of Accounting, Nanjing Audit University, Nanjing, China \\ ${ }^{3,6}$ Department of Management \& HR, NUST Business School, \\ National University of Sciences and Technology, Islamabad, Pakistan \\ ${ }^{4}$ School of Management, Asian Institute of Technology, Bangkok, Thailand \\ ${ }^{5}$ School of Accounting, Nanjing Audit University, Nanjing, China \\ ${ }^{7}$ Department of Business \& Management, IUBH University of Applied Sciences, Germany
}

Received 11 June 2020; accepted 12 May 2021

\begin{abstract}
The purpose of this research is to examine the influence of bank life cycle or bank maturity on income diversification (ID) and stability. In addition, this research investigates the ID relationship with bank stability. Drawing on the dynamic resource-based view and modern portfolio theory, this research examines the influence of a paramount internal factor i.e. bank life cycle or bank maturity on income diversification (ID) and stability consequence. Data were collected from the Pakistani's commercial banks' financial statements over the period 2005 to 2019. This research relied on the fixed effect and generalized method of moments (GMM) model to empirically test the proposed relationships. Core findings of the research reveal that bank maturity leads to enhanced ID and ID strongly influences the bank stability consequence, moreover, research findings are robust to use different measures of bank stability and GMM estimation techniques. To the authors' best knowledge, this research is the first to report specific evidence about bank maturity as an internal driver of income diversification and stability and advances the literature seeking to understand the determinants of ID. This research also shows managers to recognize the importance of internal drivers to diversify effectively into non-interest income, and how such an effective ID translates into stability consequence.
\end{abstract}

Keywords: bank life cycle, income diversification, bank stability, banking sector, GMM, Pakistan.

JEL Classification: G10, G21, G28.

\section{Introduction}

The banking sector is the mainstay of the financial system as it performs a vital intermediation role to mobilizes savings and an important lender to the different sectors of the economy.

*Corresponding author. E-mail: 320335@nau.edu.cn

Copyright (c) 2021 The Author(s). Published by Vilnius Gediminas Technical University

This is an Open Access article distributed under the terms of the Creative Commons Attribution License (http://creativecommons. org/licenses/by/4.0/), which permits unrestricted use, distribution, and reproduction in any medium, provided the original author and source are credited. 
The banking sector facilitates businesses to grow, as the banks are the main source of credit for small, medium, and large businesses in the emerging economies (Imran \& Nishat, 2013) who may lack sufficeint funds for the growth. In this regard, researchers argue that a robust banking system is essential for business growth, particularly, in emerging economies as developed and growing businesses demand more credits for the growth (Imran \& Nishat, 2013). Moreover, Anton (2019) documents that the banking sector influence high growth firms' performance as the banking sector impacts the economic growth that positively impacts sales and total assets growth of the firms.

Increased market competition results in diversification to other sources of income, mainly shifting from interest to non-interest income (Williams, 2016; Zouaoui \& Zoghlami, 2020), and the changes in the income structure affect the banking sector stability (Abedifar et al., 2018; Doan et al., 2018). Due to the increasing importance of ID and its influence on bank stability, this research empirically examines the association between bank life cycle or bank maturity, income diversification, and stability consequence.

Several scholars have investigated the impact of different drivers on the bank ID such as Pennathur et al. (2012) investigate the ownership impact on the ID and risk in the context of Indian banks and document that ownership does not influence income diversification. However, ID may lead to a reduction in risk. Ahamed (2017) examines the relationship between asset quality and ID and reports that banks with lower asset qualities are better diversified into non-interest income. Zouaoui and Zoghlami (2020) investigate the bank market power aftershocks on ID and claim that higher market power may lead to higher ID.

Although the extant literature has provided valuable evidence regarding different determinants impact on ID, however, it has not adequately addressed the influence of bank life cycle or bank maturity on ID. Firm life cycle proposes that "firms will inevitably evolve and transit from one stage of development to another. The theory posits that firms will follow a predictable pattern characterized by different stages of development which cannot be easily reversed" (Owen \& Yawson, 2010, p. 428), and firm strategies, structures, functions, capabilities, and resources vary according to its life cycle stage (Habib \& Hasan, 2017). Moreover, discussion on ID and stability is not independent of bank life cycle stages as mature banks are particularly active in non-interest income to remain competitive and increase stability. Thus, based on a dynamic resource-based view, this research argues that bank diversification into non-interest income may also be dependent on bank maturity due to their strategic resources, both financial and knowledge, established infrastructure, reputational capital, and large customer, and more likely to have higher stability (Tariq et al., 2019b). Besides, growth banks may not be able to diversify better into non-interest income because of the limited financial resources, limited customer base, and inadequate reputational capital and thus, unlikely to have better stability consequences. Earlier researchers have investigated firm maturity effect on various firms' strategies such as green process innovation (Tariq et al., 2019b) and corporate mergers and acquisitions (Owen \& Yawson, 2010). However, bank maturity influence on ID and stability has not been addressed reasonably in the burgeoning ID literature and it serves as the impetus to investigate the aforesaid relationship. Thus, the first objective of this research is to investigate the influence of bank maturity on ID and stability consequences. 
This research further examines whether ID has a positive impact on the stability consequence, the main motivation to understand this relationship originates from the studies which report an inconsistent relationship between ID and performance consequences. For instance, researchers demonstrate that income diversification may not be linked with higher stability (Abuzayed et al., 2018; Mercieca et al., 2007; Stiroh, 2004a; Zouaoui \& Zoghlami, 2020) on the other hand, several researchers have reported that income diversification enhances bank stability (Amidu \& Wolfe, 2013; Baele et al., 2007; Sanya \& Wolfe, 2011). Moreover, literature is largely limited to the US and European banking sector and limited evidences are available from emerging economies such as Pakistan. Pennathur et al. (2012) argue that findings of the studies on ID from developed countries have limited implications for emerging economies due to different factors such as lack of financial networks, limited technology, and managerial experiences. Because of the inconsistent findings and limited evidences from emerging economies, ID and banks stability relationship is still a question for discussion and needs further investigation.

To explain the ID and bank stability relationship, this research theorizes on the premise of modern portfolio theory which contends that diversified banks are likely to have positive financial performance outcomes due to economies of scope (Gavurova et al., 2017; Sharma \& Anand, 2018; Tariq et al., 2014b), and bank risk-adjusted performance which is concentrated into overall loan portfolio of the banks are likely to enhance due to diversification into non-interest income (Nisar et al., 2018). Therefore, this research sought to examine the ID and bank stability relationship to add evidences to the existing literature and the second objective of this research is to examine the relationship between ID and stability consequence. This research addresses two research questions:

RQ1. What is the influence of bank maturity on ID and stability?

RQ2. What is the influence of ID on bank stability?

This research contributes to the corporate life cycle and ID literature. First, it adds knowledge to existing literature on ID by highlighting the prominent role of the bank life cycle as its prominent determinant. This research documents that bank maturity leads to better ID due to reputational capital, a large customer base, established networks, and strong financial and knowledge resources. Secondly, it contributes by providing additional evidences on the ongoing debate about the inconsistent relationship between ID and bank stability in the context of an emerging economy. The research results are valuable and beneficial to advance theory and improve practitioners' understanding of the factor that leads to higher ID and translates it into stability consequence.

Remaining paper is structured in the following subsequent sections: firstly, this research discusses the theory and proposes hypotheses in the theory and hypotheses development section. Secondly, this research deliberated the importance of research context, variable measurement, and research models in the methodology section. Thirdly, this study discusses results based on the different estimation techniques in the result section. Finally, this research discusses and elaborated theoretical and managerial implications in the discussion section, followed by the conclusions and limitations of the research. 


\section{Theory and hypotheses development}

Understanding the bank's decisions regarding diversification into non-interest income is vital for assessing banks' stability, particularly, bank ID a prominent strategy that reduces the risk and has critical implications for performance (Amidu \& Wolfe, 2013). Prior research on ID has ignored the potential impact of bank maturity on ID and stability although researchers have emphasized that successful implementation of a firm strategy depends on its life cycle stage (Al-Hadi et al., 2016). Thus, this research examines the critical role of bank maturity on ID and stability consequences.

Penrose (1959) was the first to coin the concept of the corporate life cycle and since then several firm life cycle models have been proposed and developed over time (Owen \& Yawson, 2010). Main premise of this theory is "firms will inevitably evolve and transit from one stage of development to another. The theory posits that firms will follow a predictable pattern characterized by different stages of development which cannot be easily reversed" (Owen \& Yawson, 2010, p. 428). Empirical evidence has categorized the corporate life cycle mainly into the growth stage and maturity stage (Tariq et al., 2019b). Therefore, following the contemporary literature, this research has considered two stages, i.e. growth and maturity stages, to investigate bank maturity influence on ID (Tariq et al., 2019b).

ID refers to bank involvement in activities that create revenues from sources other than interest-based income, for instance, underwriting fees and commission income. ID can result in positive performance outcomes such as accounting and market performance. However, concurrent literature has provided both positive and negative evidences about ID influence on financial performance and requires further investigation to offer clarity for profound implications. For instance, researchers have reported that ID is not likely to result in enhanced bank stability (Abuzayed et al., 2018; Mercieca et al., 2007; Stiroh, 2004a; Zouaoui \& Zoghlami, 2020) and on the other hand, researchers have claimed that income diversification enhances bank stability (Amidu \& Wolfe, 2013; Baele et al., 2007; Sanya \& Wolfe, 2011).

\subsection{Bank maturity and income diversification}

Following Habib and Hasan (2017), Hasan and Habib (2017), this research relies on the theoretical underpinning of the dynamic resource-based view (DRBV) to comprehend the bank's maturity influence on the ID. The DRBV contends that the path and patterns of firm resources and capabilities evolve over-time (Al-Hadi et al., 2016; Penrose, 1959). Firm's resources and capabilities have implications for diversification into non-interest income as it could require resource commitment to reap better financial benefits. Banks in various life cycle phases are linked with different levels of financial resources and banks with weak financial positions are less likely to pursue ID (Hasan \& Habib, 2017). Moreover, strong internal financial resources can help firms to avoid external shocks, and firm's possession of such resources can embark on risky initiatives (Tariq et al., 2019b). Mainly, strong financial resources improve banks' capacity and chances to involve in ID that results in better stability (Anginer et al., 2018; Hasan \& Habib, 2017). In the growth stage, banks have limited internal resources and are likely to be dependent on external sources (Owen \& Yawson, 2010). Over 
time, continuous incremental innovation and growth result in the accumulation of higher unappropriated profit for mature banks, thus, mature banks need to be less dependent on external sources for financing. Moreover, mature banks have been in business for a longer period to establish a strong reputational capital, such strong reputational capital helps mature banks to earn higher profits by ID. Thus, this research argues that mature banks have higher ID due to their strong internal financial sources, higher reputational capital, and large customer base and are more stable as compared to growth stages banks.

Hypothesis 1 (a): Bank maturity has a positive influence on ID.

Hypothesis 1 (b): Bank maturity has a positive influence on bank stability.

\subsection{Income diversification and bank stability}

Literature has provided non-conclusive evidences about ID and performance relationships. One strand of literature reports that diversification is important as it improves profitability and bank stability (Abuzayed et al., 2018; Mercieca et al., 2007; Stiroh, 2004a; Zouaoui \& Zoghlami, 2020), and contrary to this, researchers argue that ID has no significant advantage and it does not help the firm to reduce the risk (Amidu \& Wolfe, 2013; Baele et al., 2007). Other researchers have reported a positive relationship between ID and financial performance (Chiorazzo et al., 2008; Lin et al., 2021; Li et al., 2021).

On the other hand, researchers argue that ID does not enhance risk-adjusted returns and improve profitability. Adesina (2021) documented that higher diversification leads to lower profitability, efficiency and stability. Stiroh (2004a) studied the consequence of ID on the US banking sector and reported that ID increases the risk and reduces profitability. Stiroh (2004b) reported that non-interest income is subject to higher instability than the regular interest income of banks. The main justification for this behavior is ID leads to increased cost, income volatility, and reduced profits for the banks (Adesina, 2021; Sanya \& Wolfe, 2011; Stiroh, 2004b).

To explain the relationship between ID and bank stability, this research theorizes on the premise of modern portfolio theory which contends that diversified banks are likely to maximize performance outcomes due to economies of scope (Sharma \& Anand, 2018), and bank risk which is concentrated into overall loan portfolio of the banks is likely to reduce due to ID (Nisar et al., 2018). Literature points out different benefits that a bank can avail by diversifying into non-interest income. The most highlighted benefits are (1) increased efficiency and reduction in total risk as ID activities are uncorrelated with the interest-based income which reduce the volatility in the earnings and increase the bank's market share (Lin et al., 2021), (2) It also generates more revenue and improves the bank's profitability (Carbo Valverde \& Rodriguez Fernandez, 2007), and (3) lastly, the existing resources of the banks can be used to minimize the cost of capital by attaining the economies of scale and scope in its operations (Goddard et al., 2008; Tariq et al., 2014a). Therefore, this research argues that ID is a source to improve bank stability, and it is hypothesize that:

Hypothesis 2: ID has a positive influence on the stability of the bank. 


\section{Methodology}

This research collected data from commercial banks of Pakistan. Haque and Tariq (2012) reported that banks of Pakistan are integral for the distribution of funds, performing important intermediation roles, and necessary to channelize funds for economic growth. Competitive dynamic environment and increased regulations have resulted in shifting commercial bank's increased focus from interest-based income to non-interest-based income in Pakistan. It is pertinent to highlight the significance of Pakistan banking sector in relation to other countries, firstly, Pakistan state has reduced ownership in the banking sector from $90 \%$ to $20 \%$, over the last three decades owing to agency cost and embedded inefficiencies, whereas in other countries, like China, Brazil, India, Egypt, Sri Lanka, Vietnam Russia, among others state still owned a major portion of ownership (Khalid \& Nadeem, 2017). This indicates low intervention from state commercial banks in the lending operations in Pakistan compared to other countries (Duprey, 2012). Secondly, Pakistan's liberalization of the banking sector limits mandatory intervention from the state for lending to priority sectors as this practice is still in place in several Asian countries. For example, in India, and Brazil banks are required to lend to priority sectors 40 and 26 percent of their total loan portfolio respectively, and this loan could be at subsidized interest (Khalid \& Nadeem, 2017). Thus, independent lending policies enabled commercial banks of Pakistan to build loan portfolios based on market factors rather than mandatory intervention. This has allowed the banking sector in Pakistan to pursue interest and non-interest-based income policies based on merit. Thirdly, unlike other economies, banking activities in Pakistan are previously restricted to local state-owned banks as foreign banks may enter with limited ownership through local companies and their equity in local institutes is not transferrable without central bank approval. It is contrary to the developed world and other financial economies where foreign bank entry is subject to limited regulations (Perera et al., 2007). However, such restrictions on private and foreign bank entry in Pakistan have been reduced and it leads to increased banking activities throughout the country. This has resulted in promoting healthy competition and the introduction of new services by the banking sector of Pakistan. Therefore, it signifies the importance of Pakistan's banking sector in relation to other countries and makes it an important context for this research.

To empirically analyze the bank maturity, ID, and stability relationship, this research collected data from the annual financial statements of Pakistan's commercial banks from 2005 to 2019. For better comprehensive and generalizable results, this study includes government banks, private banks, and Islamic banks (Perera et al., 2007). The list of banks included in this research is given in Table 1 .

Table 1. Sample summary (source: self-reported)

\begin{tabular}{|c|l|l|c|}
\hline No. & \multicolumn{1}{|c|}{ Types of Banks } & \multicolumn{1}{|c|}{ Bank Name } & Data for the No. of Years \\
\hline 1 & \multirow{4}{*}{ Government Banks } & National Bank of Pakistan & 15 \\
\cline { 4 - 4 } & & Bank of Punjab & 15 \\
\cline { 4 - 4 } & & First Woman Bank & 13 \\
\cline { 3 - 4 } & & Bank of Khyber & 15 \\
\hline 4 & & & \\
\hline
\end{tabular}


End of Table 1

\begin{tabular}{|c|c|c|c|}
\hline No. & Types of Banks & Bank Name & Data for the No. of Years \\
\hline 5 & \multirow{4}{*}{ Islamic Banks } & Meezan Bank & 15 \\
\hline 6 & & Bank Islami & 14 \\
\hline 7 & & Dubai Islamic & 15 \\
\hline 8 & & Albaraka Bank & 14 \\
\hline 9 & \multirow{14}{*}{ Private Banks } & Allied Bank & 15 \\
\hline 10 & & Askari Bank & 15 \\
\hline 11 & & Bank Al Habib & 15 \\
\hline 12 & & Bank Alfalah & 15 \\
\hline 13 & & HBL & 15 \\
\hline 14 & & UBL & 15 \\
\hline 15 & & Standard Chartered Bank & 15 \\
\hline 16 & & Soneri Bank & 15 \\
\hline 17 & & MCB Bank & 15 \\
\hline 18 & & JS Bank & 14 \\
\hline 19 & & Silk Bank & 15 \\
\hline 20 & & Faysal Bank & 15 \\
\hline 21 & & Samba Bank & 15 \\
\hline 22 & & Habib Metro Politan Bank & 15 \\
\hline
\end{tabular}

\subsection{Variables measurement}

Table 2 describes the variable measurements in this research where all measures are taken from previously established research.

Table 2. Variables measurement (source: self-reported)

\begin{tabular}{|c|c|c|c|}
\hline Variable & Description & Measurement & Reference \\
\hline \multirow{3}{*}{ BS } & \multirow{3}{*}{ Bank Stability } & $\mathrm{Z}=(\mathrm{ROA}+\mathrm{E} / \mathrm{T}) / \sigma \mathrm{ROA}$ & Amidu and Wolfe (2013) \\
\hline & & RAROA $=$ ROA $/ \sigma R O A$ & $\begin{array}{l}\text { Amidu and Wolfe (2013), Sanya and } \\
\text { Wolfe (2011) }\end{array}$ \\
\hline & & RAROE $=$ ROE $/ \sigma \mathrm{ROE}$ & $\begin{array}{l}\text { Amidu and Wolfe (2013), Sanya and } \\
\text { Wolfe (2011) }\end{array}$ \\
\hline ID & $\begin{array}{l}\text { Income } \\
\text { Diversification }\end{array}$ & $\begin{array}{l}\text { Non-interest income / } \\
\text { operating income }\end{array}$ & $\begin{array}{l}\text { Dietrich and Wanzenried (2011), } \\
\text { Heffernan and Fu (2010) }\end{array}$ \\
\hline $\mathrm{BM}$ & Bank Maturity & $\begin{array}{l}\text { Unappropriated profit / Total } \\
\text { Assets }\end{array}$ & DeAngelo et al. (2006) \\
\hline CAR & $\begin{array}{l}\text { Capital } \\
\text { Adequacy Ratio }\end{array}$ & Equity / Total Assets & $\begin{array}{l}\text { Chiorazzo et al. (2008), Mercieca et al. } \\
\text { (2007), Stiroh (2004b) }\end{array}$ \\
\hline
\end{tabular}


End of Table 2

\begin{tabular}{|l|l|l|l|}
\hline Variable & \multicolumn{1}{|c|}{ Description } & \multicolumn{1}{c|}{ Measurement } & \multicolumn{1}{c|}{ Reference } \\
\hline GDPC & $\begin{array}{l}\text { GDP Per } \\
\text { Capita }\end{array}$ & Log of GDP & Kim et al. (2020) \\
\hline LROA & Lag ROA & Lag of ROA Ratio & Kim et al. (2020) \\
\hline SZ & Bank Asset Size & Log of bank assets. & Acharya et al. (2006) \\
\hline
\end{tabular}

This research followed extant literature to measures bank stability using Z-score (Amidu \& Wolfe, 2013; Sanya \& Wolfe, 2011).

$$
Z=\frac{\mathrm{ROA}+\mathrm{E} / \mathrm{T}}{\sigma \mathrm{ROA}}
$$

The $Z$-score measure is calculated as ROA (Return on asset, net income scaled by total assets), plus $\mathrm{E} / \mathrm{T}$ (bank equity scaled by total assets), and $\sigma \mathrm{ROA}$ is the standard deviation of return on assets. Banks with higher profit and capitalization have higher stability and banks with unstable earnings and lower capitalization have lower stability. Moreover, this research also included two additional measures of stability i.e. risk-adjusted return on assets (RAROA) and risk-adjusted return on equity (RAROE) by scaling ROA and ROE by their respective standard deviation $(\sigma)$ to calculate the volatility of profits (Amidu \& Wolfe, 2013; Sanya \& Wolfe, 2011).

$$
\begin{aligned}
& \mathrm{RAR}_{\mathrm{ROA}}=\frac{\mathrm{ROA}}{\sigma \mathrm{ROA}} ; \\
& \mathrm{RAR}_{\mathrm{ROE}}=\frac{\mathrm{ROE}}{\sigma \mathrm{ROE}} .
\end{aligned}
$$

In line with the extant literature, this research measured income diversification (ID) by dividing non-interest income by operating income (Dietrich \& Wanzenried, 2011; Heffernan \& $\mathrm{Fu}, 2010)$.

$$
\text { ID }=\frac{\text { Non-interest income }}{\text { Operating income }} \text {. }
$$

Bank maturity is measured through unappropriated profit to total assets. Banks with higher unappropriated profits are mature banks as they accumulated high unappropriated profit over the long time of their operations, whereas banks with low unappropriated profit are growth banks (Tariq et al., 2019b).

$$
\mathrm{BM}=\frac{\text { Unappropriated profit }}{\text { Total Assets }} .
$$

Following the literature, this research takes into account several control variables which have an impact on bank's decision to diversify into non-interest-based income such as larger banks are more likely to diversify into non-interest income, we measured bank size by taking a log of total assets (Acharya et al., 2006). Capital adequacy ratio (CAR) is a measure to indicate the financial soundness of the bank (Chiorazzo et al., 2008; Mercieca et al., 2007). 
In line with the extant literature, this research has also included Lag of ROA Ration (LROA) and GDP Per Capita (GDPC) as an explanatory variable in this research (Kim et al., 2020). As this research consists of data before, during, and after the financial crisis, so this research have also included dummies for the financial crisis as before financial crises (BFC), during financial crises (DFC), and after financial crises (AFC) dummies to control the effect of financial crises during that period and to observe effect on research results. This research have also included Private Bank (PVTB) and Public Bank (PUBB) and Islamic Bank (IB) and Non-Islamic Bank (NIB) dummies in the research model as they can influence the results.

\subsection{Research models}

This research used the fixed-effect model initially to explore the linkages between banks' maturity, ID, and stability and for robustness, relied on GMM estimation techniques. This research removed the outliers using winsorization at $1 \%$ for the continuous variables.

$$
\begin{aligned}
& \mathrm{ID}_{i t}=\beta_{0}+\beta_{1} \mathrm{BM}_{i t}+\beta_{2} \mathrm{CAR}_{i t}+\beta_{3} \mathrm{SZ}_{i t}+\beta_{4} \mathrm{GDPC}_{i t}+\beta_{5} \mathrm{LROA}_{i t}+ \\
& \beta_{6} \mathrm{DFC}_{i t}+\beta_{7} \mathrm{AFC}_{i t}+\beta_{8} \mathrm{PVTB}_{i t}+\beta_{9} \mathrm{NIB}_{i t}+\varepsilon_{i t} \text {; } \\
& \mathrm{Z}_{\text {-Score }}{ }_{i t}=\beta_{0}+\beta_{1} \mathrm{BM}_{i t}+\beta_{2} \mathrm{CAR}_{i t}+\beta_{3} \mathrm{SZ}_{i t}+\beta_{4} \mathrm{GDPC}_{i t}+\beta_{5} \mathrm{LROA}_{i t}+ \\
& \beta_{6} \mathrm{DFC}_{i t}+\beta_{7} \mathrm{AFC}_{i t}+\beta_{8} \mathrm{PVTB}_{i t}+\beta_{9} \mathrm{NIB}_{i t}+\varepsilon_{i t} \text {; } \\
& \mathrm{RAROA}_{i t}=\beta_{0}+\beta_{1} \mathrm{BM}_{i t}+\beta_{2} \mathrm{CAR}_{i t}+\beta_{3} \mathrm{SZ}_{i t}+\beta_{4} \mathrm{GDPC}_{i t}+\beta_{5} \mathrm{LROA}_{i t}+ \\
& \beta_{6} \mathrm{DFC}_{i t}+\beta_{7} \mathrm{AFC}_{i t}+\beta_{8} \mathrm{PVTB}_{i t}+\beta_{9} \mathrm{NIB}_{i t}+\varepsilon_{i t} \text {; } \\
& \mathrm{RAROE}_{i t}=\beta_{0}+\beta_{1} \mathrm{BM}_{i t}+\beta_{2} \mathrm{CAR}_{i t}+\beta_{3} \mathrm{SZ}_{i t}+\beta_{4} \mathrm{GDPC}_{i t}+\beta_{5} \mathrm{LROA}_{i t}+ \\
& \beta_{6} \mathrm{DFC}_{i t}+\beta_{7} \mathrm{AFC}_{i t}+\beta_{8} \mathrm{PVTB}_{i t}+\beta_{9} \mathrm{NIB}_{i t}+\varepsilon_{i t} \text {. }
\end{aligned}
$$

The first equation is drafted to test hypothesis 1(a) of this research and Equations (2), (3), and (4) are drafted to test hypothesis $1(\mathrm{~b})$. Where $i$ represent bank and $t$ represents time. In equation (1), $\mathrm{ID}_{i t}$ represents income diversification as a dependent variable. In Equations ((2) to (4)) (Z-score, RAROA, RAROE) are used as a proxy of bank stability. $\beta_{0}$ is a constant term. $\mathrm{BM}_{i t}$ represents bank maturity as an independent variable, $\mathrm{CAR}_{i t}$ represents capital adequacy ratio, $\mathrm{SZ}_{i t}$ represents bank size, $\mathrm{GDPC}_{i t}$ represents $\mathrm{GDP}$ per Capita and $\mathrm{LROA}_{i t}$ represents lag of ROA ratio as a control variable. $\mathrm{DFC}_{i t}, \mathrm{AFC}_{i t}, \mathrm{PVTB}_{i t}$, and NIB are dummies. Equation (1) measures the influence of bank maturity on ID and Equation ((2), (3), (4)) measures the influence of bank maturity on stability using the fixed-effect model.

$$
\begin{aligned}
\text { Z-Score }_{i t}= & \beta_{0}+\beta_{1} \mathrm{ID}_{i t}+\beta_{2} \mathrm{CAR}_{i t}+\beta_{3} \mathrm{SZ}_{i t}+\beta_{4} \mathrm{GDPC}_{i t}+\beta_{5} \mathrm{LROA}_{i t}+ \\
& \beta_{6} \mathrm{DFC}_{i t}+\beta_{7} \mathrm{AFC}_{i t}+\beta_{8} \mathrm{PVTB}_{i t}+\beta_{9} \mathrm{NIB}_{i t}+\varepsilon_{i t} ; \\
\mathrm{RAROA}_{i t}= & \beta_{0}+\beta_{1} \mathrm{ID}_{i t}+\beta_{2} \mathrm{CAR}_{i t}+\beta_{3} \mathrm{SZ}_{i t}+\beta_{4} \mathrm{GDPC}_{i t}+\beta_{5} \mathrm{LROA}_{i t}+ \\
& \beta_{6} \mathrm{DFC}_{i t}+\beta_{7} \mathrm{AFC}_{i t}+\beta_{8} \mathrm{PVTB}_{i t}+\beta_{9} \mathrm{NIB}_{i t}+\varepsilon_{i t} ; \\
\mathrm{RAROE}_{i t}= & \beta_{0}+\beta_{1} \mathrm{ID}_{i t}+\beta_{2} \mathrm{CAR}_{i t}+\beta_{3} \mathrm{SZ}_{i t}+\beta_{4} \mathrm{GDPC}_{i t}+\beta_{5} \mathrm{LROA}_{i t}+ \\
& \beta_{6} \mathrm{DFC}_{i t}+\beta_{7} \mathrm{AFC}_{i t}+\beta_{8} \mathrm{PVTB}_{i t}+\beta_{9} \mathrm{NIB}_{i t}+\varepsilon_{i t} .
\end{aligned}
$$


Equations ((5) to (7)) measures hypothesis 2 by investigating the effect of ID on bank stability (Z-score, RAROA, RAROE) using the fixed effect model, whereas Z-score, RAROA, and RAROE are used as a proxy of bank stability.

$$
\begin{aligned}
& \mathrm{ID}_{i, t}=\beta_{0}+\beta_{1} \mathrm{ID}_{i, t-1}+\beta_{2} \mathrm{BM}_{i, t}+\sum_{K=1}^{K} \beta_{K} X_{i, t}^{K}+\sum_{T=1}^{T-1} \beta_{T} D_{T}+\mu_{\mathrm{i}}+\varepsilon_{i, t} \\
& \text { Z-Score }_{i, t}=\beta_{0}+\beta_{1} \text { Z-score }_{i, t-1}+\beta_{2} \mathrm{BM}_{i, t}+\sum_{K=1}^{K} \beta_{K} X_{i, t}^{K}+\sum_{T=1}^{T-1} \beta_{T} D_{T}+\mu_{\mathrm{i}}+\varepsilon_{i, t} \text {; } \\
& \text { RAROA }_{i, t}=\beta_{0}+\beta_{1} \text { RAROA }_{i, t-1}+\beta_{2} \mathrm{BM}_{i, t}+\sum_{K=1}^{K} \beta_{K} X_{i, t}^{K}+\sum_{T=1}^{T-1} \beta_{T} D_{T}+\mu_{\mathrm{i}}+\varepsilon_{i, t} \\
& \operatorname{RAROE}_{i, t}=\beta_{0}+\beta_{1} \operatorname{RAROE}_{i, t-1}+\beta_{2} \mathrm{BM}_{i, t}+\sum_{K=1}^{K} \beta_{K} X_{i, t}^{K}+\sum_{T=1}^{T-1} \beta_{T} D_{T}+\mu_{\mathrm{i}}+\varepsilon_{i, t} \\
& \text { Z-Score }_{i, t}=\beta_{0}+\beta_{1} \mathrm{Z}_{\text {- } \text { core }_{i, t-1}}+\beta_{2} \mathrm{ID}_{i, t}+\sum_{K=1}^{K} \beta_{K} X_{i, t}^{K}+\sum_{T=1}^{T-1} \beta_{T} D_{T}+\mu_{\mathrm{i}}+\varepsilon_{i, t} \\
& \mathrm{RAROA}_{i, t}=\beta_{0}+\beta_{1} \mathrm{RAROA}_{i, t-1}+\beta_{2} \mathrm{ID}_{i, t}+\sum_{K=1}^{K} \beta_{K} X_{i, t}^{K}+\sum_{T=1}^{T-1} \beta_{T} D_{T}+\mu_{\mathrm{i}}+\varepsilon_{i, t} ; \\
& \operatorname{RAROE}_{i, t}=\beta_{0}+\beta_{1} \operatorname{RAROE}_{i, t-1}+\beta_{2} \mathrm{ID}_{i, t}+\sum_{K=1}^{K} \beta_{K} X_{i, t}^{K}+\sum_{T=1}^{T-1} \beta_{T} D_{T}+\mu_{\mathrm{i}}+\varepsilon_{i, t} .
\end{aligned}
$$

This research relied on GMM to test the robustness of results and check the endogeneity problems. GMM estimation technique is adequate for dynamic panel dataset as it contains small and large banks which are subject to unobserved fixed-effects and endogeneity between explained and explanatory variables (Blundell \& Bond, 1998). Equation (8) measures the influence of bank maturity on ID based on the GMM estimation technique. Equations ((9) to (11)) and Equations ((12) to (14)) used different measures of bank stability (Z-score, RAROA, RAROE) as dependent variables. This research measures the influence of bank maturity on bank stability in Equations (9) to (11) and the influence of ID on bank stability in Equations (12) to (14).

\section{Results}

Descriptive statistics of the research are given in Table 3 where all the correlation values are well below the threshold level of 0.70 , suggesting a low probability of multicollinearity in the analysis. This research also performed variance inflation factor (VIF) test to check the multicollinearity and found no evidence of the existence of multicollinearity, all the values lie between 1.06 to 1.70 (Tariq et al, 2019a). To check the existence of autocorrelation and heteroscadicity in the research data, this research performed the 


\begin{tabular}{|c|c|c|c|c|c|c|c|c|c|c|c|c|c|c|c|c|c|}
\hline 10 & & & & & & & & & & & & & & & & & $\begin{array}{l}n \\
n \\
0 \\
i\end{array}$ \\
\hline$\Xi$ & & & & & & & & & & & & & & & & $\begin{array}{l}2 \\
\overrightarrow{0} \\
1\end{array}$ & $\begin{array}{l}\stackrel{R}{1} \\
0 \\
i\end{array}$ \\
\hline 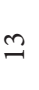 & & & & & & & & & & & & & & & $\begin{array}{l}\text { Oे } \\
\dot{1}\end{array}$ & $\begin{array}{l}0 \\
0 \\
0 \\
1\end{array}$ & 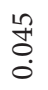 \\
\hline$\simeq$ & & & & & & & & & & & & & & $\begin{array}{l}0 \\
\stackrel{1}{0} \\
i\end{array}$ & \begin{tabular}{l}
\multirow{H}{*}{} \\
$\dot{0}$ \\
0
\end{tabular} & $\begin{array}{c}0 \\
0 \\
0 \\
0\end{array}$ & $\begin{array}{l}\text { LO } \\
\stackrel{\varphi}{0}\end{array}$ \\
\hline$\Xi$ & & & & & & & & & & & & & సิ & ก̂? & $\begin{array}{l}10 \\
0 \\
0 \\
0\end{array}$ & $\begin{array}{l}\tilde{O} \\
\dot{O} \\
0\end{array}$ & $\begin{array}{l}\text { Oे } \\
\text { î }\end{array}$ \\
\hline$\circ$ & & & & & & & & & & & & $\begin{array}{l}\hat{a} \\
\hat{i}\end{array}$ & \begin{tabular}{l}
\multirow{H}{*}{} \\
$\stackrel{1}{1}$
\end{tabular} & \begin{tabular}{l}
0 \\
\multirow{n}{0}{} \\
0
\end{tabular} & $\begin{array}{l}+ \\
8 \\
0 \\
0\end{array}$ & \& & $\begin{array}{l}8 \\
\dot{1}\end{array}$ \\
\hline$a$ & & & & & & & & & & & 命 & $\frac{0}{0}$ & 㝘 & $\begin{array}{l}2 \\
0 \\
0 \\
1\end{array}$ & $\begin{array}{l}2 \\
0 \\
0 \\
0\end{array}$ & $\frac{9}{9}$ & $\frac{\infty}{\infty}$ \\
\hline$\infty$ & & & & & & & & & & 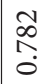 & $\begin{array}{l}\overrightarrow{6} \\
-1 \\
0\end{array}$ & 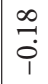 & $\begin{array}{l}n \\
\hat{0} \\
0 \\
0\end{array}$ & $\begin{array}{l}0 \\
0 \\
0 \\
i\end{array}$ & $\begin{array}{l}\overrightarrow{0} \\
0 \\
0\end{array}$ & 官 & $\begin{array}{l}1 \\
\infty \\
0 \\
0\end{array}$ \\
\hline$\wedge$ & & & & & & & & & $\begin{array}{l}\vec{\infty} \\
\stackrel{0}{0}\end{array}$ & $\begin{array}{l}\infty \\
\hat{6} \\
0 \\
0\end{array}$ & $\stackrel{\overrightarrow{I n}}{\overrightarrow{0}}$ & $\begin{array}{l}0 \\
-1 \\
0 \\
1\end{array}$ & : & $\begin{array}{l}0 \\
0 \\
0 \\
1\end{array}$ & $\overrightarrow{0}$ & 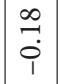 & $\underset{0}{\rightleftarrows}$ \\
\hline 6 & & & & & & & & $\begin{array}{l}\overrightarrow{0} \\
0 \\
0\end{array}$ & $\stackrel{\beth}{\exists}$ & $\stackrel{n}{\rightrightarrows}$ & $\begin{array}{l}10 \\
0 \\
0 \\
0\end{array}$ & $\begin{array}{l}\overrightarrow{0} \\
0 \\
i\end{array}$ & 㝘 & $\begin{array}{l}8 \\
0 \\
0 \\
1\end{array}$ & ț & $\begin{array}{c}0 \\
\cdots \\
0 \\
1\end{array}$ & $\begin{array}{l}\text { Iै } \\
\text { Oे }\end{array}$ \\
\hline in & & & & & & & 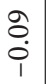 & $\frac{2}{0}$ & 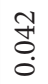 & $\stackrel{\Re}{\stackrel{f}{+}}$ & ¿̊ & $\begin{array}{l}0 \\
0 \\
\dot{\rho}\end{array}$ & $\begin{array}{l}0 \\
0 \\
0 \\
i\end{array}$ & 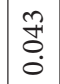 & $\begin{array}{l}0 \\
10 \\
0 \\
i\end{array}$ & \begin{tabular}{l}
$\infty$ \\
\multirow{N}{*}{} \\
0 \\
1
\end{tabular} & $\stackrel{\sim}{\stackrel{1}{0}}$ \\
\hline H & & & & & $\begin{array}{l}\infty \\
\stackrel{9}{?} \\
0\end{array}$ & & $\begin{array}{l}\overrightarrow{0} \\
0 \\
\dot{0}\end{array}$ & $\frac{n}{\circ}$ & 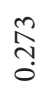 & ڤે & ô & $\vec{F}$ & 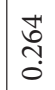 & 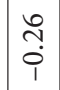 & $\begin{array}{l}2 \\
\tilde{3} \\
\hat{1}\end{array}$ & \begin{tabular}{l}
$\infty$ \\
\hdashline \\
$i$ \\
$i$
\end{tabular} & ڤે \\
\hline$m$ & & & & $\begin{array}{l}\text { กิ } \\
\text { i }\end{array}$ & $\stackrel{\infty}{\stackrel{0}{0}}$ & & $\begin{array}{l}\stackrel{N}{S} \\
\stackrel{0}{0}\end{array}$ & $\underset{\text { ठิ }}{\stackrel{0}{0}}$ & $\stackrel{-}{0}$ & 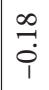 & $\begin{array}{l}\text { Ju } \\
\text { O }\end{array}$ & $\begin{array}{l}m \\
0 \\
0\end{array}$ & $\begin{array}{l}\infty \\
0 \\
0 \\
0 \\
1\end{array}$ & $\begin{array}{l}\hat{\Delta} \\
0 \\
0\end{array}$ & 命 & సે & $\stackrel{\infty}{\stackrel{\infty}{i}}$ \\
\hline$\sim$ & & & $\begin{array}{l}\text { ô. } \\
\text { iे }\end{array}$ & ֶิ & $\begin{array}{l}0 \\
\stackrel{7}{*} \\
\stackrel{0}{*}\end{array}$ & & $\begin{array}{l}+ \\
0 \\
0 \\
\end{array}$ & $\begin{array}{l}\hat{\sigma} \\
\text { n̊. } \\
0\end{array}$ & $\stackrel{\sim}{\stackrel{0}{0}}$ & 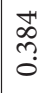 & 苞 & $\begin{array}{l}0 \\
0 \\
0 \\
1\end{array}$ & ণి & ڤ̊ & $\begin{array}{l}20 \\
0 \\
0 \\
1\end{array}$ & $\begin{array}{l}\vec{H} \\
\stackrel{0}{0} \\
i\end{array}$ & 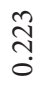 \\
\hline- & & 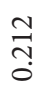 & $\begin{array}{l}\stackrel{m}{n} \\
\stackrel{1}{1}\end{array}$ & 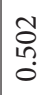 & $\stackrel{\sim}{\dddot{m}}$ & & $\begin{array}{l}\stackrel{0}{0} \\
\dot{0} \\
1\end{array}$ & $\begin{array}{r}n \\
\text { ֻे } \\
0\end{array}$ & $\begin{array}{l}0 \\
\tilde{n} \\
\tilde{0}\end{array}$ & 굴 & $\begin{array}{l}\infty \\
0 \\
0 \\
1\end{array}$ & $\begin{array}{l}\text { no } \\
\text { Oे } \\
0\end{array}$ & $\begin{array}{l}n \\
0 \\
0 \\
0\end{array}$ & 今o & $\stackrel{8}{8}$ & $\begin{array}{l}2 \\
0 \\
0 \\
1\end{array}$ & $\begin{array}{l}8 \\
\stackrel{0}{0}\end{array}$ \\
\hline iे & $\begin{array}{l}\dot{0} \\
\stackrel{0}{0}\end{array}$ & Oे. & గ̂م & $\begin{array}{l}\infty \\
\infty \\
i \\
0\end{array}$ & ๙ै & & 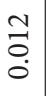 & $\begin{array}{l}\stackrel{P}{1} \\
m \\
m\end{array}$ & $\stackrel{0}{\stackrel{0}{\circ}}$ & $\begin{array}{l}\mathfrak{\sigma} \\
\check{\sigma} \\
\sigma\end{array}$ & 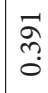 & $\begin{array}{l}n \\
\infty \\
n \\
0\end{array}$ & $\begin{array}{l}0 \\
\text { ஸे } \\
0\end{array}$ & $\begin{array}{l}\text { ڤ̊ } \\
\text { ஸे } \\
0\end{array}$ & ڤ̊ & 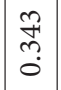 & ث্+ \\
\hline$\stackrel{\Xi}{\stackrel{\Xi}{\Xi ँ ~}}$ & $\begin{array}{l}\text { L } \\
\stackrel{8}{0} \\
\dot{0}\end{array}$ & $\begin{array}{l}\text { 우 } \\
\stackrel{1}{-}\end{array}$ & $\begin{array}{l}\hat{\infty} \\
\infty \\
0 \\
0\end{array}$ & $\stackrel{\infty}{\infty}$ & $\begin{array}{l}\stackrel{1}{\sigma} \\
\dot{m}\end{array}$ & & $\vec{\Xi}$ & 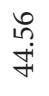 & ๗ેa & $\frac{+}{\sigma}$ & $\underset{\infty}{\stackrel{2}{0}}$ & 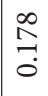 & $\begin{array}{l}0 \\
0 \\
0 \\
0 \\
0\end{array}$ & $\stackrel{+}{\stackrel{2}{\circ}}$ & $\frac{n}{2}$ & $\begin{array}{l}\stackrel{n}{7} \\
\stackrel{0}{0}\end{array}$ & $\underset{0}{\overrightarrow{\widehat{\sigma}}}$ \\
\hline & $\sum_{\substack{\infty \\
-i}}$ & $\begin{array}{l}\theta \\
i\end{array}$ & $\begin{array}{l}\text { 究 } \\
\dot{m} \\
\dot{m}\end{array}$ & $\begin{array}{l}\text { N } \\
\text { r }\end{array}$ & $\begin{array}{l}0 \\
\text { 今े } \\
\text { जि } \\
\text { ம. }\end{array}$ & & 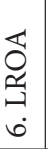 & 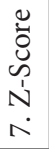 & 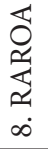 & 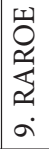 & $\begin{array}{l}\stackrel{p}{1} \\
\stackrel{2}{2} \\
0 \\
0\end{array}$ & 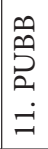 & 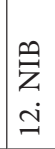 & $\begin{array}{l}\mathscr{\theta} \\
\ddot{\sim}\end{array}$ & 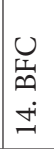 & 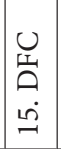 & $\begin{array}{l}0 \\
\text { 㫕 } \\
\dot{0} \\
\dot{-1}\end{array}$ \\
\hline
\end{tabular}


FGLS test, as it overcomes the problem of autocorrelation and heteroscadicity. Besides, this research also performed xtserial command to check the autocorrelation and xttest3 command to check the heteroscadicity (Baum, 2001). We did not find autocorrelation and heteroscadicity issues in this research.

Table 4 provides the result of the fixed-effect model and checks the influence of bank maturity on dependent variables: ID and bank stability. Firstly, in model 1, this research estimated equation 1 which indicates that bank maturity has a positive significant influence on income diversification at a 5\% significant level, supports hypothesis 1 (a) and it shows that mature banks have better income diversification. Secondly, models 2, 3, and 4 represent Equations (2), (3), and (4) respectively which measured the bank maturity influence on different bank stability measures (Z-score, RAROA \& RAROE). To simplify the relationships, this research comprehensively used proxies of risks adjusted performance measures to amount bank stability variables (Amidu \& Wolfe, 2013) and found a positive and significant influence of bank maturity on bank stability at a $1 \%$ significant level. Results highlight that a bank's maturity has a positive influence on stability measures. Thirdly, in models 5, 6, and 7, this research estimated Equations (5), (6), and (7) respectively which show the direct relationship of ID on bank stability, and findings indicate that in all three cases (Z-score, RAROA \& RAROE) the ID positively and significantly influences all bank stability measures at $1 \%$ significant level that enhance risk-adjusted performance which supports the theory that ID of banks has a positive impact on the stability consequence. Control variable capital adequacy ratio and bank size also show a direct relationship with ID and bank stability measures whereas bank size is significant in the entire model. It establishes that larger banks are likely to pursue ID and are stable compared to small banks.

Following contemporary literature and robustness check, this research also used GMM estimation techniques to examine the linkages between bank maturity, ID, and bank stability in Table 5. Firstly, in model 8, this research estimated equation 8 which reaffirms proposed hypothesis that bank maturity has a positive significant influence on ID at 5\% significance level and supports hypothesis 1(a) which shows that mature banks have better income diversification. Secondly, in models 9, 10, and 11, this research estimated Equations (9), (10), and (11), which measure the bank maturity influence on different bank stability measures (Z-score, RAROA \& RAROE). However, only one measure Z-score significant at the $10 \%$ level, and the remaining measures show no significant relationship that shows results do not partially support hypothesis 1 (b) that bank maturity leads to bank stability. Thirdly, in model 12, 13, and 14, this research estimated Equations (12), (13), and (14) respectively and it reconfirms the relationship in Table 4 that ID strongly enhances risk-adjusted bank performance and stability in all three cases (Z-score at 5\% significance level, RAROA at 10\% significance level, \& RAROE at 10\% significance level) and supports hypothesis 2 . It means that income diversification has contributed positively to the performance of the Pakistani banks. This research did not notice any change in the influence of control variables on ID and stability in Table 5 and the results are consistent with the Table 4 . 


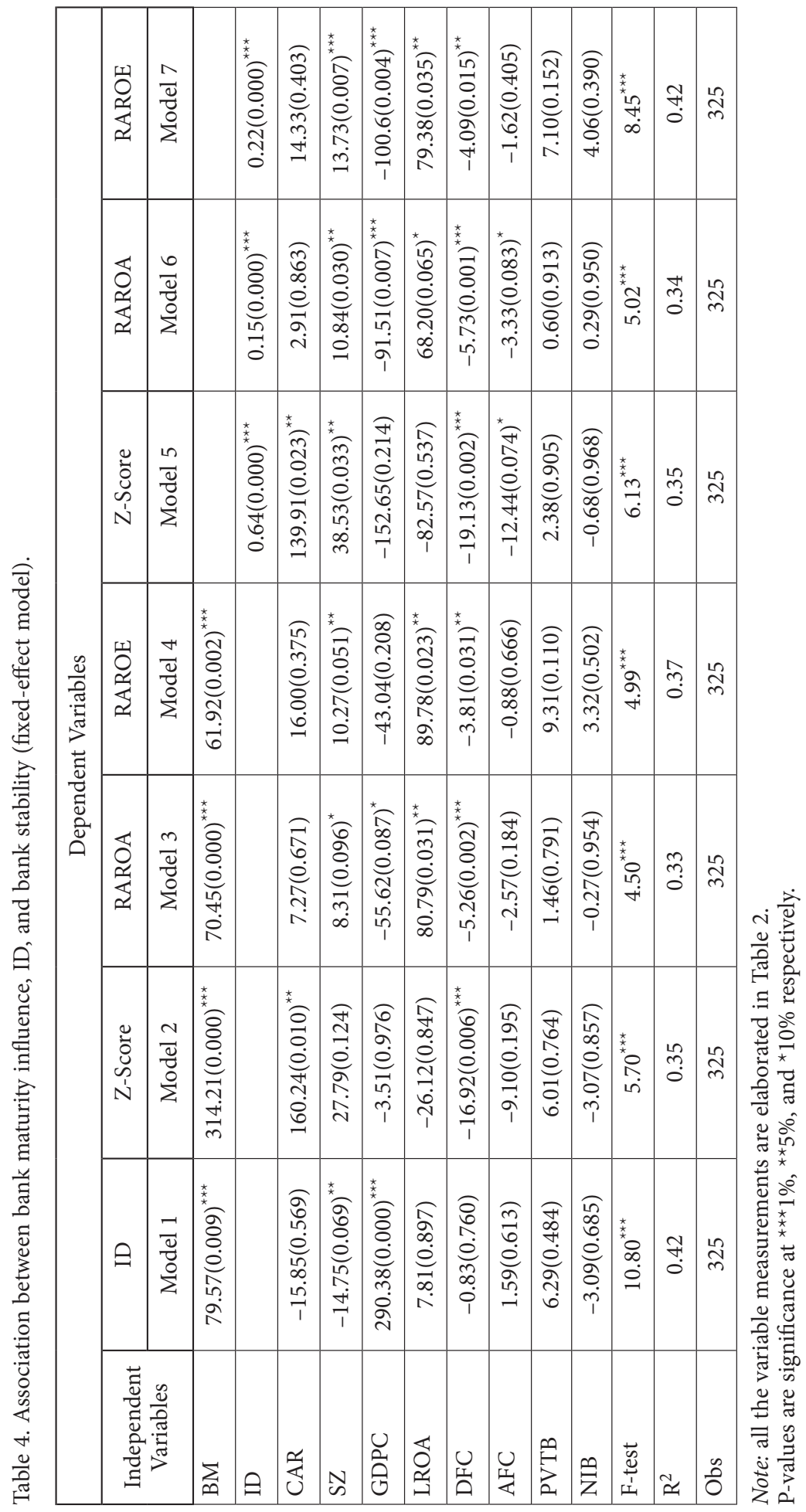




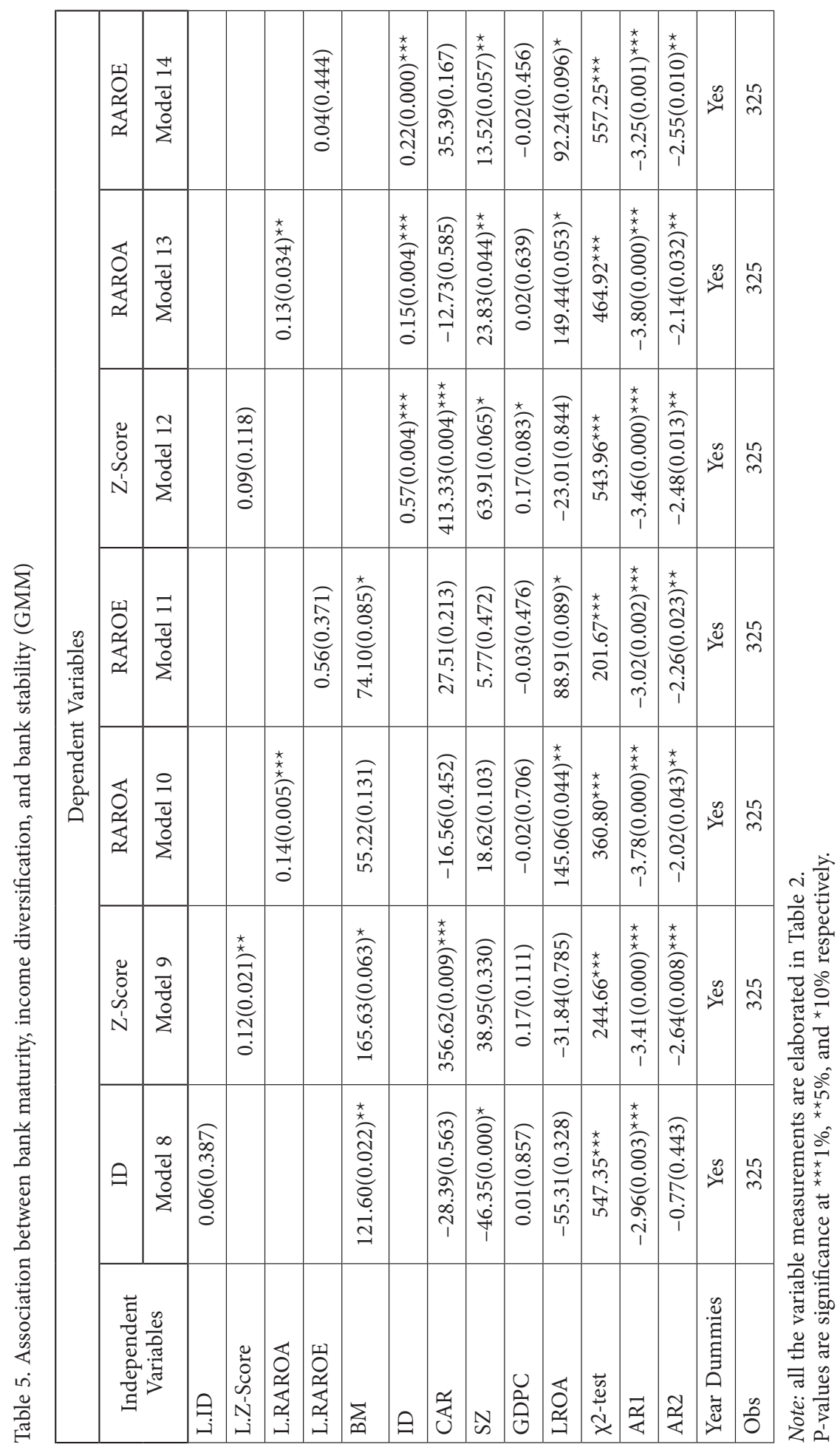




\section{Discussions}

Commercial banks utilize ID as a non-price based contemporary strategy to increase market share, to minimize the risk, and to increase returns. By aligning the dynamic resource-based view and modern portfolio theory, this research analyzed the linkages between bank maturity, ID, and stability. Results findings are in favor of the proposed hypothesis that bank maturity has a significant influence on income diversification. It indicates that mature banks are more likely to diversify their income in non-traditional income sources due to strong financial resources, large customer base, reputational capital, established infrastructure, and knowledge resources compared to growth banks. Moreover, bank maturity has a significant influence on the overall stability of the bank owing due to continuous growth, enhance customer base, and the ability to attract new customers from new services due to diversification.

Such diversification provides banks leverage to increase revenues, respond effectively to environmental changes and enhance stability, these findings are in accordance with existing literature (Tariq et al., 2019b; Zouaoui \& Zoghlami, 2020). This research also examines the influence of ID on bank stability and finds that ID has a favorable significant influence on bank stability. Result findings demonstrate that ID increases the financial soundness of the bank, enhances revenues, mobilizes savings, reduces financial risks that lead to increased bank stability. Our research findings are in line with modern portfolio theory which claims that diversification is likely to result in enhanced stability of the banks (Nisar et al., 2018; Sharma \& Anand, 2018). Together, these findings imply that mature banks are more likely to pursue ID, and ID has a favorable influence on bank stability.

This research also examines the influence of ID on bank stability and finds that ID has a favorable significant influence on bank stability. Result findings demonstrate that ID increases the financial soundness of the bank, enhances revenues, mobilizes savings, and reduces financial risks that lead to increased bank stability. These research findings are in line with modern portfolio theory which claims that diversification is likely to result in enhanced stability of the banks (Nisar et al., 2018; Sharma \& Anand, 2018). Together, these findings imply that mature banks are more likely to pursue ID, and ID has a favorable influence on bank stability.

\section{Implications}

By integrating dynamic resource-based view and modern portfolio theory, these research findings have supplemented the burgeoning literature on ID with mainly two academic implications. Firstly, consistent with the dynamic resource-based view, this research analyzes bank maturity as an internal driver of income diversification and finds that bank maturity leads to increased income diversification. This suggests that mature versus growth banks may respond differently to income diversification whereas mature banks are more likely to engage and have higher income diversification. By doing so, this research is the first to report and contribute specific evidence about bank maturity as an internal driver of income diversification and therefore, advances the literature seeking to understand the determinants of income diversification. Additionally, this research has added theoretical insights to the academic 
literature by establishing a relationship between bank maturity and stability, it describes that bank maturity leads to increased stability of the banks. Secondly, drawing on modern portfolio theory, this research has shed further light on the ongoing debate that echoes the ID and bank stability relationship. This research proposes and discovers that increasing income portfolios in non-interest incomes has a positive impact on stability. In this manner, this research has provided fine-grained evidence relating to an ongoing debate about ID and bank stability relationships.

Eventually, this research gives vital insights for the corporate executives and managers seeking to diversify income into non-interest income and enhance stability from it. Since effective diversification into non-interest income requires resources, and it may vary across banks at different life cycle stages, managers of mature banks may utilize their networks and financial and knowledge resources efficiently to diversify into non-interest income. Moreover, strong internal financial resources can help a firm to avoid external shocks and firm possession of such resources can embark on initiatives such as diversification into non-interest income. Therefore, corporate executives and managers may need to recognize the importance of internal drivers for diversification into non-interest income. Moreover, managers need to comprehend the significance of income diversification as it may offer banks an opportunity to enhance stability by increasing efficiency, generating more revenues, and utilizing existing resources to attain economies of scale and scope. Thus, managers can maximize performance outcomes and minimize risk which is concentrated into the overall loan portfolio of the banks by diversifying into non-interest income. These results are helpful for the executives and managers in their interpretation to capitalize on and enhance performance from income diversification. Thus, this research has contributed to the existing literature on ID and the corporate life cycle by highlighting and analyzing the prominent role of bank maturity as its determinant. This research has shed further light on the nexus between ID and the stability of the banks to offer clarity on the ongoing debate.

\section{Conclusions}

By drawing on the theoretical landscape of dynamic resource-based view and modern portfolio theory, this research considers the role of bank maturity as an antecedent of ID and bank stability and makes some unique contributions to ID and corporate life cycle literature. Consistent with the literature and based on the data collected from an emerging economies bank, this research used different measures of risk as a proxy for bank stability and run fixed effect and GMM estimation model to empirically investigate the proposed relationships. Research findings show that bank maturity has a significant influence on ID as mature banks are more likely to diversify their income due to their existing competitive advantage and availability of financial resources. Thus, considering bank maturity as an antecedent of income diversification, this research advances the literature on income diversification.

Moreover, research findings indicate that ID leads to stability as diversified banks can manage overall risk, especially risk arises from income volatility. By doing so, this research contributed to the ongoing debate on ID and bank stability that better ID can favorably influence bank stability. Thus, core findings reveal that bank maturity exerts a significant positive 
influence on ID. Moreover, ID as uncorrelated with interest income significantly links to the overall financial stability of the banks. This research has shed valuable insights for policymakers, managers, and academicians about bank maturity's role in ID and stability. This research also finds that when subject to the GMM estimation technique, this research finds that bank maturity does not lead to bank stability.

This research's findings suffer from certain limitations. Firstly, the main limitation of this research is related to the low sample size which is data consists of 22 commercial banks only and collected over the limited period from 2005 to 2019. Moreover, this research relied on the data set from a single country i.e. Pakistan, thus, future studies are highly encouraged to address these limitations by using cross country data, data collected over a longer period, and increase the number of banks in their research for the better generalizability of their findings. Secondly, this research relied on a single measure for bank maturity as used extensively in the extant literature, nevertheless, researchers argue that there is no best measure; therefore, it is suggested to test the model utilizing different measures to enhance results generalizability.

Lastly, this research considers only two stages of the bank life cycle, it is suggested to consider other stages of the life cycle such as the decline and introduction stage.

\section{Funding}

China National Social Science Fund Project (21BGL008); Jiangsu “333” Project [BRA2019271] and the Priority Academic Program Development and Sino-Foreign Joint Scientific Research Platform of Jiangsu Higher Education Institutions.

\section{Authors contribution}

All authors have contributed equally in this article.

\section{Disclosure statement}

Authors do not have any competing financial, professional, or personal interest from other parties.

\section{References}

Abedifar, P., Molyneux, P., \& Tarazi, A. (2018). Non-interest income and bank lending. Journal of Banking \& Finance, 87, 411-426. https://doi.org/10.1016/j.jbankfin.2017.11.003

Abuzayed, B., Al-Fayoumi, N., \& Molyneux, P. (2018). Diversification and bank stability in the GCC. Journal of International Financial Markets, Institutions and Money, 57, 17-43. https://doi.org/10.1016/j.intfin.2018.04.005

Acharya, V. V., Hasan, I., \& Saunders, A. (2006). Should banks be diversified? Evidence from individual bank loan portfolios. The Journal of Business, 79(3), 1355-1412. https://doi.org/10.1086/500679

Adesina, K. S. (2021). How diversification affects bank performance: The role of human capital. Economic Modelling, 94, 303-319. https://doi.org/10.1016/j.econmod.2020.10.016 
Ahamed, M. M. (2017). Asset quality, non-interest income, and bank profitability: Evidence from Indian banks. Economic Modelling, 63, 1-14. https://doi.org/10.1016/j.econmod.2017.01.016

Al-Hadi, A., Hasan, M. M., \& Habib, A. (2016). Risk committee, firm life cycle, and market risk disclosures. Corporate Governance: An International Review, 24(2), 145-170. https://doi.org/10.1111/corg.12115

Amidu, M., \& Wolfe, S. (2013). Does bank competition and diversification lead to greater stability? Evidence from emerging markets. Review of Development Finance, 3(3), 152-166. https://doi.org/10.1016/j.rdf.2013.08.002

Anginer, D., Demirgüç-Kunt, A., \& Mare, D. S. (2018). Bank capital, institutional environment and systemic stability. Journal of Financial Stability, 37, 97-106. https://doi.org/10.1016/j.jfs.2018.06.001

Anton, S. G. (2019). Leverage and firm growth: an empirical investigation of gazelles from emerging Europe. International Entrepreneurship and Management Journal, 15(1), 209-232. https://doi.org/10.1007/s11365-018-0524-5

Baele, L., De Jonghe, O., \& Vander Vennet, R. (2007). Does the stock market value bank diversification? Journal of Banking \& Finance, 31(7), 1999-2023. https://doi.org/10.1016/j.jbankfin.2006.08.003

Baum, C. (2001). XTTEST3: Stata module to compute Modified Wald statistic for groupwise heteroskedasticity.

Blundell, R., \& Bond, S. (1998). Initial conditions and moment restrictions in dynamic panel data models. Journal of econometrics, 87(1), 115-143. https://doi.org/10.1016/S0304-4076(98)00009-8

Carbo Valverde, S., \& Rodriguez Fernandez, F. (2007). The determinants of bank margins in European banking. Journal of Banking \& Finance, 31(7), 2043-2063. https://doi.org/10.1016/j.jbankfin.2006.06.017

Chiorazzo, V., Milani, C., \& Salvini, F. (2008). Income diversification and bank performance: Evidence from Italian banks. Journal of Financial Services Research, 33(3), 181-203. https://doi.org/10.1007/s10693-008-0029-4

DeAngelo, H., DeAngelo, L., \& Stulz, R. M. (2006). Dividend policy and the earned/contributed capital mix: a test of the life-cycle theory. Journal of Financial Economics, 81(2), 227-254. https://doi.org/10.1016/j.jineco.2005.07.005

Dietrich, A., \& Wanzenried, G. (2011). Determinants of bank profitability before and during the crisis: Evidence from Switzerland. Journal of International Financial Markets, Institutions and Money, 21(3), 307-327. https://doi.org/10.1016/j.intfin.2010.11.002

Doan, A.-T., Lin, K.-L., \& Doong, S.-C. (2018). What drives bank efficiency? The interaction of bank income diversification and ownership. International Review of Economics \& Finance, 55, 203-219. https://doi.org/10.1016/j.iref.2017.07.019

Duprey, T. (2012). Bank Ownership and Credit Cycle: the lower sensitivity of public bank lending to the business cycle. World Bank Group. https://doi.org/10.2139/ssrn.2185859

Gavurova, B., Belas, J., Kocisova, K., \& Kliestik, T. (2017). Comparison of selected methods for performance evaluation of Czech and Slovak commercial banks. Journal of Business Economics and Management, 18(5), 852-876. https://doi.org/10.3846/16111699.2017.1371637

Goddard, J., McKillop, D., \& Wilson, J. O. (2008). The diversification and financial performance of US credit unions. Journal of Banking \& Finance, 32(9), 1836-1849. https://doi.org/10.1016/j.jbankfin.2007.12.015

Habib, A., \& Hasan, M. M. (2017). Firm life cycle, corporate risk-taking and investor sentiment. Accounting \& Finance, 57(2), 465-497. https://doi.org/10.1111/acfi.12141

Haque, A., \& Tariq, A. (2012). Efficiency of banks in Pakistan: A non parametric approach. Business and Economic Research, 2(1). https://doi.org/10.5296/ber.v2i1.1711 
Hasan, M. M., \& Habib, A. (2017). Corporate life cycle, organizational financial resources and corporate social responsibility. Journal of Contemporary Accounting \& Economics, 13(1), 20-36. https://doi.org/10.1016/j.jcae.2017.01.002

Heffernan, S. A., \& Fu, X. (2010). Determinants of financial performance in Chinese banking. Applied Financial Economics, 20(20), 1585-1600. https://doi.org/10.1080/09603107.2010.505553

Imran, K., \& Nishat, M. (2013). Determinants of bank credit in Pakistan: A supply side approach. Economic Modelling, 35, 384-390. https://doi.org/10.1016/j.econmod.2013.07.022

Khalid, A., \& Nadeem, T. (2017). Bank credit to private sector: A critical review in the context of financial sector reforms (pp. 1-25). State Bank of Pakistan.

Kim, H., Batten, J. A., \& Ryu, D. (2020). Financial crisis, bank diversification, and financial stability: OECD countries. International Review of Economics \& Finance, 65, 94-104. https://doi.org/10.1016/j.iref.2019.08.009

Li, X., Feng, H., Zhao, S., \& Carter, D. A. (2021). The effect of revenue diversification on bank profitability and risk during the COVID-19 pandemic. Finance Research Letters, 101957. https://doi.org/10.1016/j.frl.2021.101957

Lin, Y., Shi, X., \& Zheng, Z. (2021). Diversification strategy and bank market power: Does foreign ownership matter? Applied Economics Letters, 28(4), 269-273. https://doi.org/10.1080/13504851.2020.1751798

Mercieca, S., Schaeck, K., \& Wolfe, S. (2007). Small European banks: Benefits from diversification? Journal of Banking \& Finance, 31(7), 1975-1998. https://doi.org/10.1016/j.jbankfin.2007.01.004

Nisar, S., Peng, K., Wang, S., \& Ashraf, B. (2018). The impact of revenue diversification on bank profitability and stability: Empirical evidence from South Asian countries. International Journal of Financial Studies, 6(2), 40. https://doi.org/10.3390/ijfs6020040

Owen, S., \& Yawson, A. (2010). Corporate life cycle and M\&A activity. Journal of Banking \& Finance, 34(2), 427-440. https://doi.org/10.1016/j.jbankfin.2009.08.003

Pennathur, A. K., Subrahmanyam, V., \& Vishwasrao, S. (2012). Income diversification and risk: Does ownership matter? An empirical examination of Indian banks. Journal of Banking \& Finance, 36(8), 2203-2215. https://doi.org/10.1016/j.jbankfin.2012.03.021

Penrose, E. T. (1959). The theory of the growth ofthe firm. Sharpe.

Perera, S., Skully, M., \& Wickramanayake, J. (2007). Cost efficiency in South Asian banking: The impact of bank size, state ownership and stock exchange listings. International Review of Finance, $7(1-2)$, 35-60. https://doi.org/10.1111/j.1468-2443.2007.00067.x

Sanya, S., \& Wolfe, S. (2011). Can banks in emerging economies benefit from revenue diversification? Journal of Financial Services Research, 40(1-2), 79-101. https://doi.org/10.1007/s10693-010-0098-Z

Sharma, S., \& Anand, A. (2018). Income diversification and bank performance: evidence from BRICS nations. International Journal of Productivity and Performance Management, 67(9), 1625-1639. https://doi.org/10.1108/IJPPM-01-2018-0013

Stiroh, K. J. (2004a). Diversification in banking: Is noninterest income the answer? Journal of Money, Credit and Banking, 36(5), 853-882. https://doi.org/10.1353/mcb.2004.0076

Stiroh, K. J. (2004b). Do community banks benefit from diversification? Journal of Financial Services Research, 25(2-3), 135-160. https://doi.org/10.1023/B:FINA.0000020657.59334.76

Tariq, A., Badir, Y., \& Chonglerttham, S. (2019a). Green innovation and performance: moderation analyses from Thailand. European Journal of Innovation Management, 22(3), 446-467. https://doi.org/10.1108/EJIM-07-2018-0148

Tariq, A., Badir, Y. F., Safdar, U., Tariq, W., \& Badar, K. (2019b). Linking firms' life cycle, capabilities, and green innovation. Journal of Manufacturing Technology Management, 31(2), 284-304. https://doi.org/10.1108/JMTM-08-2018-0257 
Tariq, W., Ali, I., Ibrahim, M., Asim, M., \& Rehman, N. U. (2014a). Theory and empirical evidence on corporate governance from Banking sector of Pakistan. Business and Economic Research, 4(1), 163-174. https://doi.org/10.5296/ber.v4i1.5180

Tariq, W., Usman, M., Mir, H. Z., Aman, I., \& Ali, I. (2014b). Determinants of commercial banks profitability: Empirical evidence from Pakistan. International Journal of Accounting and Financial Reporting, 4(2), 1-22. https://doi.org/10.5296/ijafr.v4i2.5939

Williams, B. (2016). The impact of non-interest income on bank risk in Australia. Journal of Banking \& Finance, 73, 16-37. https://doi.org/10.1016/j.jbankfin.2016.07.019

Zouaoui, H., \& Zoghlami, F. (2020). On the income diversification and bank market power nexus in the MENA countries: Evidence from a GMM panel-VAR approach. Research in International Business and Finance, 52, 101186. https://doi.org/10.1016/j.ribaf.2020.101186 